Vol. 1, No. 3, 2016. (www.indianstudies.net/v1n3)

PDF: http://www.indianstudies.net//V1/n3/v1n3s110.pdf

DOI: https://dx.doi.org/10.21659/bp.v1n3.s110

(c) AesthetixMS

\title{
Exploring Emotive Narrative Techniques to Illuminate Cult Writings in Mahasweta Devi's Rudali and K. Balachander's Aval Oru Thodarkathai
}

\author{
Mohankumar S \& Dr. V. Vijayalakshmi \\ VIT University, Chennai.Email: mohankumar.s2o16@vitstudent.ac.in
}

\begin{abstract}
Indianism could be the word that has the power to explain Indian culture, habit, heritage, richness, unity, food, and power of literature. On the other hand, it would be same word that would elucidate humiliation and disgrace endured by throng of its population because of 'caste' discrimination which has paved way for inhuman communal rites and rituals. This research article thrives to discuss the emotional state of mind of under privileged people by exploring the emotive narrative techniques used by Mahasweta Devi in Rudali and Aval Oru Thodarkathai of K. Balachander that also has the basics of cult writings. Various pangs and pains undergone by populace of disadvantage community especially because of the label 'Dalit' they carry are illustrated in this research article.
\end{abstract}

Keywords: Rudali, Aval Oru Thodarkathai, Economical state, Caste, Religion, Communal rites, Poverty, Womanhood, Battle of life.

\section{Introduction}

India is labelled as secular nation and it is always remembered with much-loved and always recited slogan "unity in diversity". Is it so? Still now, India is filled with people who fight for their identity. There is a question on India's identity as has India as a whole failed to accept all its populace? Or has it failed to recognize the feelings of people who fight for their identity? Most of the Indian writings pictures only about the regional, language, community, religion and cultural hurdles. From classical writers to modern writers, they find some fault with beliefs and habits in India. Instead of using the word fault, it would be better to use "search for identity and recognition". Mahasweta Devi and K. Balachander through their Rudali and Aval Oru Thodarkathai (Kabitha in Bengali) respectively have made it possible to raise these questions to the mass. There are millions of people left out in the fringes of our society because of their caste, financial status, occupation, education and so on? Through Rudali and Aval Oru Thodarkathai, the great non-stereotype writers have brought to the light the life of such thrown off people. This present research article has focussed on the emotive narrative techniques used by these stalwarts in depicting these issues which also occupies the qualities of cult fiction and movie.

\section{Style and narrative techniques}

Narrative style is very elegant in writings of Mahasweta Devi. She never beats around the bush in the name of philosophy or revolutionary ideology. She narrates the life of common man using the

(c) AesthetixMS 2016. This Open Access article is published under a Creative Commons Attribution Non-Commercial 4.0 International License (http://creativecommons.org/licenses/by-nc/4.o/), which permits non-commercial re-use, distribution, and reproduction in any medium, provided the original work is properly cited. For citation use the DOI. For commercial re-use, please contact aesthetixms@gmail.com. 
narrative adhered by day today conversation. Characters of Mahasweta Devi carry myriads of emotions and passions. Mahasweta Devi always chooses her plot and characters from backward or suppressed community and is successful in expressing their pains and yearnings in her intellectual quotient of narrative modus operandi. Mahasweta Devi's almost all characters are still inspiring many youngsters as these characters are considered as role models in their life. Mahasweta Devi is a master in converting sting and pain endured by the oppressed community into words and powerful expressions. Instead of just portraying their pain, she takes an extra attempt and probes to the root cause of their problems and reflects on all the trauma of their real life through her explicit writing. Mahasweta is not a writer who just fits in the frame of feminist and feminism rather is a humanist.

K.Balachander is a renowned film director in India. He also had unique style in presenting ideas and represents the problems in life of women. Rather than talking about particular issue, Balachander also use to narrate their whole life and makes the audience and readers to understand the seriousness of challenges and problems in their life. Every film of Balachander has an element and style of biography. Similar to Mahasweta, he handles words in effective way in the form of regular usage.

To objective of this research article is to understand and explore the emotive narrative techniques of Mahasweta and K.Balachander concentrating on legendary work of their career Rudali and Aval Oru Thodarkathai . Though Mahasweta has carved many more works, her Rudali stands as her identity and as a mark of success in her career. Similarly, K.Balachander's Aval Oru Thodarkathai is still in the research perusal of many aspirants as this movie has well brought to lime light the then revolutionary and daring attitude of womanhood in the most lucid comportment.

Mahasweta in Rudali narrates the life of Sanichari a woman from underprivileged community. Rudali culture and custom may not be known by all. Rather than posing a direct attack on the caste system forced upon the populace in an unconscious process with an intention to bring inequality by government, Mahasweta expressed the emotions of particular sect people through her emotive narrative. Understanding emotions of other is not an easy task, but Devi did that and achieved success. She never used the character Sanichari as her mouthpiece but she lends her heart to express the pain of Sanichari and community which that characters belongs.

Aval Oru Thodarkathai, talks about the routine life of the protagonist Kavitha. Economy and a few cultural ideologies decide the life of many people in India. Balachander has not attacked the Indian culture and government policies but he has created awareness by paving way for global understanding about the seriousness of how cultural imbalance and economical condition acts as a fate decider of many misfortunate people. Balachander movies are known for emotions. He has the power to express the emotions experienced by others in a very subtly effective way. In this film, he has portrayed the life of woman, who belongs to middle class in economy level and male dominated working environment.

\section{Trash or trashed?}

Rudali and Aval oru Thodarkathai is interlinked in a plethora of ways especially in narrative techniques. Rudali and Aval oru Thodarkathai have reached the zenith of success as it stands unique in articulating the soreness and lifestyle of women belonging to the embryonic society. Sanichari and Kavitha are even today accepted and celebrated for their balanced emotions and facing the society. Mahasweta Devi's Rudali and Aval oru Thodarkathai of Balachander is from two different parts of India in spite of geographical difference, cultural dissimilarity, one thing that 
has unite them is the facet of poverty. Sanichari and Kavitha are treated as trash because of their inability to cope with the status of the privileged people economically.

Sanichari and Kavitha nowhere tried to label them as the feminists through their life they only tried to protect themselves from befalling a victim to the clutches of cultural clutch and economical crunch. Irony to be noted is there are still many who considered these characters as representation of feminism rather than humanism. This is where Mahasweta and Balachander has reached the epitome of success as every issues of the society is pictured in a very lucid but in a pragmatic sense leaving to the readers to comprehend it in ways they want it to be. Writings of both these legends in art have created awareness for centuries together of how human beings treat their kind in the vindictive manner just because of their caste and economic background. These two great works came out in the same period, 1970's and the scenes penned down by them has given a question is the representatives of womanhood Sanichari and Kavitha are trash or are they made trash? Adding to this question, there are myriads of examples from the works chosen were it could add on to the justification that they are trashed to be a trash. Writings and narrative style of Devi and Balachander should be considered and celebrated as cult fiction and movies as there are traces and qualities of cult literature in their works.

\section{Cult}

"Cult" is a word which is often confused by many people. Religion, theology, philosophy, psychological trauma are often confused and is associated with cult. This research article attempts to explore the nuances of cult prevailing in Rudali and Aval Oru Thodarkathai and how it occupies the genre of cult works through emotive narratives. Cult film and writings is always known for controversial ideas and could also be stated that it stands unique as it breaks the boundaries of injected cultural norms. The narrative technique is not followed or used based on conventional rules. Unusual methods are adopted to bring originality and uniqueness in work. Cult writings are notable for its revolutionary ideas and prophecy. It does not follow or obey the beliefs and systems of the society. Cult writers pave the way for their generation. It makes the audience and readers to think and act. Devi and Balachander adopted this style as their weapon and begun their career in new dimension. Even after 40 years of the works published, every one quoted and do research on Rudali and Aval Oru Thodarkathai. This reason is enough to argue and prove that how both of them dwell in the brand "cult writers".

\section{Elements of Cult}

A Few major techniques used in cult writings are intertextual references, open ending, nostalgic effects. Anatomy, consumption, political economy, cultural statuses are considered as four major elements in cult out of these four only one particular element takes the major role. It differs according to writer and situation.

Present research article focuses on the role of two cult elements in analysed in the writings of Devi and Balachander they are political economy and cultural status. These two things are clearly expressed in almost all the writings of Devi and Balachander. When it comes to Rudali and Aval Oru Thodarkathai, the elements of political economy and culture dominates. Sanichari and Kavitha plunge a prey to the economic instability and cultural dogmas of this society.

\section{Political Economy}

Devi talks about serious problem of India and suppressed life of women in independent India. She is not under any colonised government. India is always known for the respect towards women but Sanichari lead life in miserable way. What makes her voice as dumb and turned as unnoticed? 
Devi has raised all these questions then explained the crucial role played by political economy in tarnishing the life of Sanichari. Many incidents in the life of Sanichari prove the power of political economy.

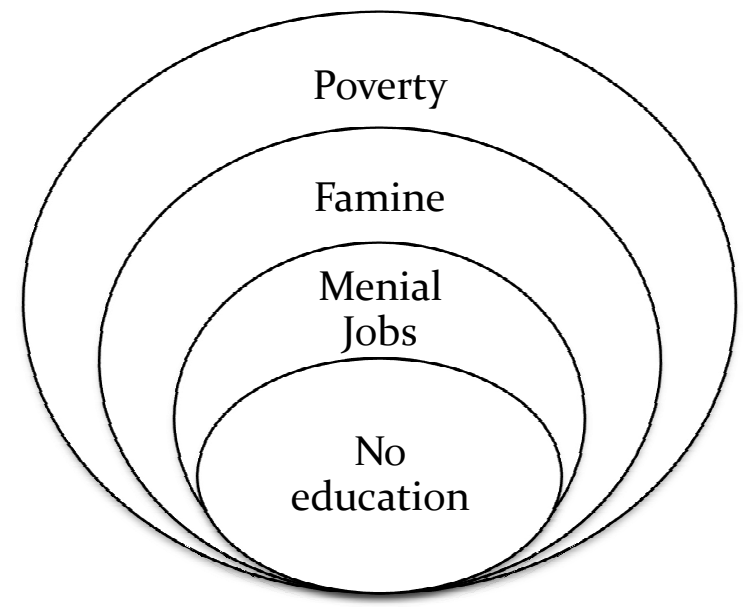

(CHART 1 Represents the Link Between Political Economy and Deteriorated Life)

The above chart represents how far the life of people below poverty line gets distorted because of an economic imbalance. The very first task for any government is to ensure safety for food, shelter and education to people. If it so, why Sanichari is forced to choose her life flanked by two horrible things that is prostitute or rudali? Is it a policy of government for women? Indian politics always have two different ideologies. Dr.B.R Ambedkar fought for education and equality, he states that, "to deny them that right(education) is to create a situation full of injustice. To keep people illiterate and then to make their literacy the ground of their enfranchisement is to add insult to injury". (Arundhati Roy) At that same time, Mahatma Gandhi wants and asks people to do their traditional jobs based on caste. Result and impact of Gandhian ideologies create worst situation in India, especially in the life of poor.

In Rudali, one landlord lament for his relation death, at that time he states that "Hai! Chacha! As long as you were alive, the lower caste never dared raise their heads. For fear of you the sons of dushads and Gangu never dared attend government schools! Now who will take care of all these things?"(68). This single statement gives clear idea about political economy confusions in India and how it reflects in the life of common man, here, the aim and dream of Father of Indian Law itself is shattered. Is restricting someone from learning is not a crime? Or is it a law? Devi expressed her anger and raised her question towards government through the voice of landlord itself. It is a brilliant tactics that she has espoused for her quotient of writing.

After this, Devi stands in the side of poor and makes a comic satire in the name of innocence from the words of Sanichari. Indian government failed to protect the people from poverty and disease. Once Sanichari post a question like a child with innocence but it carries the pain of poor people that is "Sanichari puts on an air and asks, but I heard that the upper caste never get small pox? That is was a disease of the poor and lower castes? That is why we take the government vaccination as well as appease the gods". ${ }^{50)}$ It is a perfect attack on religious ideas, political system, government policies and upper castes. Sanichari's statement is not at all out of inexperience; it is an ideological representation of Ambedkar. As mentioned earlier in this article, Devi never used her characters as mouthpiece for her. Through these two incidents she allows her 
characters to speak and makes the readers to think and understand the seriousness of political and economical issue.

Similar to Rudali, K.Balachander also has adopted this kind of narrative technique in his film Aval Oru Thodarkathai. He makes minor characters to speak in order to expose the truth and attacks the politics. Introduction scenes in K.Balachander's movies are classical one. He narrates the story from the very first moment of film.

In this film, he made a perfect attack on Communism and Capitalism ideology in the first scene itself. He used one minor character, which belongs to working class and have interest in take part in strikes. That working class man carries one box and collects the donation for labour welfare. By this picturisation and scene, he explains that how communism concept is misunderstood and taught in working class people's life. Communism never ask any labour to quit job in the name of strike, it insists them only to fight for their rights. In India, the concepts and principles of communism were misunderstood in that time. K.Balachander taught the real sense of communism through showing the dark side of it.

The earlier 1970's was known for its economic stagnation and it results with high unemployment and inflation. K.Balachander has taken this issue and reflected it through the character of Moorthi, brother of Kavitha. He is an unemployed young man, but he is bequeathed enough to borrow money from others through his intellectual and clear talk about Indian economical problem. It is an intellectual begging. Through this character, the director creates the awareness about reason behind unemployment and made a fun on government economical policy. K.Balachander's unemployed young man gives lot and lot of suggestion to India's finance minister; it is an one another genuine attack and unique narrative style.

Rudali and Aval Oru Thodarkathai reflect the political-economic issues and confusions in India through different dimension of narrative.

\section{Culture}

"Culture makes people understand each other better. And if they understand each other better in their soul, it is easier to overcome the economic and political barriers. But first they have to understand that their neighbour is in the end, just like them, with the same problems, the same questions" - Paulo Coelho

India is always glorified for its rich culture and heritage. That same culture is the barrier and curse for poor people. Indian culture has so many excellent marks to be proud of but it spoiled the life of large number of people because of caste system. The caste system is the really curse for India's development. Many leaders tried to abolish this system but they failed due to various reasons. If the writers try to bring some reformation, they are labelled as Dalit writers.

Mahasweta Devi is very careful in handling this issue. She used her narrative technique as a tool to capture the original and dark side of Indian culture. Root for this caste system is Hindu religion. Hindu religion has many superstitious belief and set of rules only for poor people. In Rudali, Sanichari faced many problems mainly because of she was born on Saturday.

"In Tahad village, gangus and dushads were in majority. Sanichari was a Gangu by birth. Like other villagers her life too was lived in desperate poverty. Her mother - in - law used to say it was because Sanichari was born on inauspicious Saturday that her destiny was full of suffering. (To which Sanichari would tell herself) Huh! Because I was born on and named after a Saturday that made me unlucky daughter - in -law! You were born on a 
Monday - was your life happier? Somri, Budha, Moongri, Bishri - do any of them have happier live?" (Rudali 54)

This incident alone can make her life as pathetic one. Her mother in law always blamed Sanichari's birth on inauspicious Saturday and then she claimed that is the reason for all sufferings and misfortune in their life. For this, Devi made a clear attack on superstitious belief and educates the reasons through the question of Sanichari that is "huh! Because was born on and named after a Saturday that made me an unlucky daughter - in-law! You were born on Monday. Was your life any happier? This is a question raised by Sanichari towards stupidity in Hindu religion. This question is a search for her identity. It is not only about her identity, it is a voice against Vedas and Puranas.

Once again the role of Gandhiji is crucial and confused regarding the caste system. Gandhian ideologies reflect and celebrate the varanasrama mentioned in The Bagavad Gita, a holy book for Hinduism. In 1950, Independent India's constitution banned discrimination on the basis of caste, it try to bring justice and it announced quotas in government jobs and education system. Even in later part of 1970's also the evil of caste system makes the poor people to suffer. Devi narrated this historic flaw through the information and explained the social setup of Tahad village in Rajasthan. In Tahad village, the Ganju is a caste; they lead desperate life in poverty and domination from other higher caste people.

Rudali this term is used to describe them as 'mourners' or lady weepers. (Encyclopedia)

The Gangu people were suppressed in the name of caste, and it label them as whore.

"it is the women who are ruined by the Malik Mahajans who turns into whores"(Rudali 8o).

What makes others to compel Rudali's to weep for upper class people's death. Mourning and weeping is closely attached to love and care but here they weep and mourn because of material domination. It is the psychological torture and trauma that is imposed on for marginalised caste. When they raise their voices or cry for their rights, upper class people starts to suppress them through religious and cultural ideas.

Upper class people ask the Ganju women to choose their option to lead their life as prostitute or Rudali. Is this is the culture in India? Who implemented this caste system and hierarchy? Being a Rudali is also equivalent to be a prostitute the only difference between these two is, one affects physiological and another one is psychological. Shedding tears for others are divine in philosophical sense but it should be happen out of empathy. In the life of rudali, it is a compulsion. Devi makes the readers to understand this situation and pain through using black comedy which depicts the real face of upper class and materialistic world that is "Amongst us, when someone dies, we all mourn. Amongst the rich, family members are too busy trying to find the keys to safe. They forget all about tears". (Devi Ganguli 7o). Through this writing Mahasweta has given a crystal view about culture and role of upper caste in the life of poor. She did not lament or blame the culture but she torches out the other side of culture. In the life of Rudali, culture itself stands as barriers for their growth. If they fail or disobey to follow that, they earned the label of prostitution which is considered as stigma in society.

K.Balachander takes different role when it comes to describe the stabbing ideologies of culture and made an attack on it. Devi explained the life of rudali to describe cultural disadvantages but Balachander narrated the life of modern woman and explained all the challenges she faced in the name of culture. Kavitha is modern according to her family and work 
place. She goes to office with all modern make-up and she is the bread winner of her family due to poverty. At one stage, her own family insults her in the name of cultural value. Kavitha is packed of emotions and ethics but she is not ready to follow that in tradition way. She never laments for her situation. She struggles and overcome all the hurdles which are in the name of culture.

Moorthi, brother of Kavitha affronted his sister for using lipstick, eyeliner, flowers and modern embroidery sarees. He compared his own sister to prostitute. The whole family accepted his habit of drinking alcohol but they failed to understand the pain of Kavitha.

Devi's Sanichari and K.Balachander's Kavitha experienced same situation but in different setup. Kavitha lost all her relationship because of her challenging and revolutionary characters. The deep root for all problems of Kavitha is her father. He left her family in the name of hermitage (Thuravi). Balachander has handled the depiction of Kavitha in perfect way like Devi did with Sanichari. Kavitha used to makes mocking comment because of anger about ancient tradition, culture, politics, relationships and role of women in this society.

In her family, no one loves the attitude and ideas of Kavitha. At the same time, they get their breads only because of her. From starting to end, Balachander managed the emotions of Kavitha helping her to stand and represent the role of woman who live with cultural challenges and social discrimination.

\section{Emotive Narrative Technique}

Various situations discussed earlier in this research article helps to understand and analyse how Devi and Balachander used their emotions in balanced way and implemented it in their narrative techniques in a very diplomatic way. Both of them have adopted two different cultural backgrounds and economical state in society but they expressed their ideas in unique way of narration. They never allow readers to lament or get empathy and sympathy; they kindle their emotions to think about root of all evil. Kindling other's emotions through writing is an art. Emotional level of Devi and K.Balachander's are same, but they create ripples of emotions among readers and audience. Their ideas and emotions carried and passed only through characters which they create. That is the reason for classical position of Sanichari and Kavitha in the history of Indian literature.

To put it in nut shell, in Rudali, Devi has mentioned that "this kind of weeping has no emotion, it is only for belly's sake and there is no bigger God than one's belly “(69). This is a perfect example and gem for an emotive narrative. This sentence alone makes the readers to think about poverty, culture and caste system problems in the life of Sanichari. In Balachander's Aval Oru Thodarkathai, Kavitha mentioned that "why I am doing is just acting. I want to remove this mask and want to lead a life". This word of Kavitha reflects the pain and challenges in her life. It is an emotion which can make audience to think in different dimensions.

What makes them to choose emotive narrative technique? 'sanichari' and kavitha' represents the whole women and lower- classes in India. Rather than pouring anger in writing and earn wrath from others, these two writers create the awareness through emotive way of teaching. Ideas are revolutionary one but they pass that to young generation through their unique way of narration. In 2016, also everyone wonders and praises the works of Devi and K.Balachander. Though the traditional gap is there but what makes them to connect with generation over generation, the reason is the emotive narrative. 


\section{Conclusion}

Emotions have power to do everything and anything in this world. Concept of Rudali is now get minimizing, the pains of Kavitha are now understood by others. The aim and dream of Devi and Balachander came into reality. The present generation celebrates these two as an icon and an identity for their development. The impact of their writings still dominates the minds of readers and audience. Rather than registering the history, Devi and Balachander represent their ideas which help to find solutions through day today incidents and conversations. These two legends belong to same period and they have unique style to represent their problems with same ideology. Devi is widely accepted and celebrated in Tamil Nadu. Many of her writings are prescribed in the syllabus of many colleges and schools. Bengali version of Aval Oru Thodarkathai is titled as "kabita". Mala Sinha starred in this movie and hit the blockbuster. It is not only about the relationship between Tamil Nadu and Bengal, it shows and proves their theme as an universal one. After the harmonious relationship between Bharathiyar and Rabindranath Tagore, it is the time to think and rejoice the intellectual relationship between Devi and K.Balachander. They can connect two states through their art and makes the world to think through their emotive narrative.

\section{References}

Ambedkar. (1986). Complete Works. Bombay: Govt. of Maharashtra. vo1.2, pg 34

Ambedkar. (2012). “I Have a Dream” for Dalits of India. Ambedkar's Caravan. Retrieved from https://drambedkarbooks.com/2012/o1/11/i-have-a-dream-for-Dalits-of-india.

Arundhati. (2014). The Doctor and the Saint Ambedkar, Gandhi and the battle against caste. Retrieved from http://www.caravanmagazine.in/essay/doctor-and-saint

Beck,Tony and Bose ,Tirthankar. (1995) "Dispossession, Degradation and Empowerment of Peasantry and the Poor itı Bengali Fiction," Economic and Political Weekly: 30 441-48.

Biswas, A K.(2013). Is India the Most Dangerous Place For Dalit Women? Mainstream. VOL 8, Pub. FEB 15.

Chakravarty, Uma. (1993).Conceptualizing Brahmanical Patriarchy in Early India: Gender, Caste, Class and State, Economic and Political Weekly $28: 579-85$

Devi, Mahasweta. Rudali. Trans. Anjum Katyal. (1990). Calcutta. Seagull. Pg 8o, 54, 55

Encyclopedia. Definition of Rudali. Retrieved from www.encyclo.co.uk/meaning-of-Rudaali

Jha Kumar, Ajit.(2016). The Dalits still Untouchable.India Today. Retrieved from http://indiatoday.intoday.in/story/Dalits-untouchable-rohith-vemula-caste-discrimination/1/58710 o.html

Pandey Rajnesh. (2014). U.R. Anantha Murthy's Samskara and Mahasweta Devi's Rudali: An Attempt to Voice the Unvoiced. RSIRJLE. ISSN 2320-6101. Vol.2.Issue - III.

Mr.Mohankumar $\mathbf{S}^{\mathbf{1}}$ is a Doctoral Degree Researcher of VIT University Chennai and is pursuing research in emotional intelligence focusing on ELT- Interdisciplinary Approaches to Literature and Arts.

Dr. V. Vijayalakshmi ${ }^{2}$ is serving as Assistant Professor in School of Science and Languages of VIT University Chennai and has more than 25 years of teaching experience and is also guiding Doctoral degree researchers. 